\title{
Introduction: Approaching Julian
}

\author{
Stefan Rebenich and Hans-Ulrich Wiemer
}

The Roman Emperor Flavius Claudius Julianus died more than one and a half millennia ago - on the 26 th of June $363 \mathrm{AD}$, only 20 months after the beginning of his sole reign. Nevertheless, his figure still arouses emotions to this day, with reactions ranging from fervent admiration to strong disapproval. Whoever deals with Julian necessarily takes sides. It starts with the name: Those who use the name Julian the Apostate single out his religious attitude as the defining characteristic of his personality and his reign. Those who prefer to call him the emperor Julian place him in the long line of Roman emperors. Admirers of Julian usually hold a critical attitude towards the alliance between emperor and church that was forged by Constantine the Great, Julian's uncle. In this camp, Julian is considered an enlightened and tolerant monarch - a philosopher in an emperor's garb, who fought Christianity in order to preserve or rather restore Greek culture in its true, unadulterated form. He held lofty ideals and led an exemplary way of life. He was a great general and statesman: According to his admirers, Julian saved Gaul from devastation at the hands of Germanic barbarians by his spirited warfare along the Rhine. In the east, he intended to put an end to the constant attacks of the Persians through offensive military operations. Above all, however, Julian strove for a fundamental reform of the late Roman 'coercive state'. He diminished the tax burden, reduced the court staff, curbed the central bureaucracy, and strengthened municipal self-government. Julian also wanted to reverse the tendency toward an 'absolutist' understanding of the empire, which does not recognize any legal restrictions. The fact that the emperor in the end utterly failed does not, on this view, reflection his aims or capabilities. His failure was rather due to a contingent event, his early death.

Views like these are still held today by renowned historians. In a German handbook on the history of the late Roman Empire, one reads:

1 Translated from German by Christopher Reid. 
Among the statesmen of Late Antiquity, Julian is the most compelling figure. He confronted his century with great vigor, fighting against the German tribes and the Persian Empire, against absolutism and bureaucracy, against popular cynicism which rejected civilization, and against Christianity, which questioned the oldest traditions of ancient religion and the highest values of the Hellenic spirit. Julian tried to elevate the conventional belief in the gods to a philosophical sun-religion in which Christianity was tolerated and even served as a model for the conduct of life and for charitable work. It was upon such renewed cultural foundations that the wavering Roman Empire was to find its footing again. ${ }^{2}$

Critical voices, however, have prevailed for some time among historians. More than a few see in Julian an ascetic visionary who advocated an obsolete religion and so necessarily failed. His notion of the gods and the right way to worship them was so esoteric and idiosyncratic that not even those who were neither Christians nor Jews were able to follow him. Julian actually wanted to destroy Christianity and only renounced openly persecuting it because all those who had used coercion and violence against the Christians before him had failed in their objectives. Since he identified his own vision with the will of the gods, he was willing to use any means possible in the struggle to attain and preserve power - whether that meant deception and lies or instigating war and civil strife. He brought the empire to the brink of disaster twice: first in 36o, when he initiated a civil war by elevating himself to the rank of Augustus without permission from his co-emperor Constantius; second in 363, when he began a war of aggression against the Persian Empire, which ended with a severe defeat. On closer inspection, the proponents of this view maintain, Julian's supposed reform program turns out to have been a mixture of ad hoc measures taken with the aim of courting supporters and clever propaganda that deliberately concealed continuity with his predecessors. Julian incessantly explained and justified himself and his policies in public, because he had without authority seized the rank of Augustus and because he wanted to impose on his

2 Demandt, Die Spätantike, p. 134: "Unter den Staatsmännern der Spätantike ist Julian die ansprechendste Gestalt. Von hohem Schwung getragen, ist er gegen sein Jahrhundert in die Schranken getreten: gegen Germanen und Perser, gegen Absolutismus und Bürokratie, gegen den populären Kynismus, der die Kultur ablehnt, und das Christentum, das die ältesten Überlieferungen antiker Religion und die höchsten Werte des hellenischen Geistes in Frage stellte. Julian versuchte, den überlieferten Göttergauben zu einer philosophischen Sonnenreligion zu erheben, in der das Christentum geduldet wurde, ja sogar das Vorbild für Lebensführung und Liebesarbeit abgab. Auf den so erneuerten Grundlagen der Kultur sollte das wankende Imperium Romanum wieder Halt finden". 
subjects a religion that the majority rejected. In short: Both as a writer and as a legislator Julian tried to compensate for his lack of legitimacy as a usurper and a conservative revolutionary.

Julian is a polarizing figure. Like few other rulers of antiquity, he effectively serves as a foil for modern ideas and programs; his image is imbued with beliefs, hopes, and fears that seem to elicit partisanship. For some, Julian is an enlightened and tolerant monarch who wanted to reform the state and society according to principles that are considered liberal in modernity. Others see him as a conservative reformer who fought for threatened cultural values, or as a reactionary who fought for a religion that was doomed to extinction. Still others understand Julian as a usurper who knew no scruples when it came to attaining and holding onto power. For them, he was a religious fanatic who wanted to destroy Christianity and only refrained from violence for tactical reasons. It is no wonder, then, that Julian's precise motives are highly controversial. Was he really an apostate from Christianity, as his opponents claimed? Is it true at all that as a child and youth he sincerly confessed to a belief in Christ which he abandoned as a grown-up? Or was his participation in Christian rites merely due to the pressure of external circumstances? Were this the case, Julian would always have remained true to himself and any discussion of his apostasy or conversion would be beside the point. After he had become sole emperor Julian made no secret of his aversion to Christianity. But where did his distaste come from? Was it the result of philosophical reflection, religious experience, or childhood trauma? The only thing that seems certain is that, as sole ruler of the Roman Empire, Julian strove to renew the cult of the ancient gods - in this respect, his well-documented deeds speak for themselves. (See Hans-Ulrich Wiemer in Ch. VII)

Since Julian represents the historical alternative to Constantine the Great, his name inevitably comes up in historically informed debates about the role of Christianity in society and the state. Critics of the Roman Catholic Church still see Julian as a victim of systematic defamation. ${ }^{3}$ Already in 1578 , Michel de Montaigne in one of his "Essais" explicitly criticised the view that Julian had been a persecutor of the Christian church: If it was true that Julian did not value the Christians, Montaigne declared, he also did not violently persecute them. His superstition deserved pity, but his virtues admiration. ${ }^{4}$ The French Enlightenment held Julian in high regard. Montesquieu, for instance, praised

3 Deschner, Kriminalgeschichte des Christentums, vol. 1, pp. 324-39.

4 Montaigne, Essais 2, 19: "C'estoit, à la verité, un très grand homme et rare, comme celuy qui avoit son ame vivement tainte de discours de la philosophie, ausquels il faisoit profession de regler toutes ses actions; et, de vray, il n'est aucune sorte de quoy il n'ait laissé de très notables exemples". 
him as a bold general and ruler. ${ }^{5}$ Diderot saw in him a philosophical eclectic and tolerant ruler who anticipated the principles of the Enlightenment. ${ }^{6}$ Voltaire put Julian on an equal footing with Marcus Aurelius, the ideal ruler par excellence, and advised Frederick II of Prussia to take him as a role model. ${ }^{7}$ Voltaire edited Julian's anti-Christian pamphlet "Against the Galilaeans" and never tired of praising him as an archetype of tolerance. Karl Marx confessed to having a weakness for Julian. ${ }^{8}$ After the Second World War, the Russian-born French philosopher Alexandre Kojève (1902-1968) interpreted the emperor as an agnostic who had promoted the ancient gods simply because he had recognized the greater danger in Christianity. ${ }^{9}$ In the 19 th and 2oth centuries, Julian repeatedly inspired poets and authors, including the Prussian Romantic writer Joseph von Eichendorff (1788-1857), the French Romantic poet Alfred de Vigny (1797-1863), the Norwegian playwright Henrik Ibsen (1828-1906), the Egyptiot Greek poet Konstantinos Cavafy (1863-1933), the Russian novelist Dimitri Sergejewitsch Merezhkovsky (1866-1941) and the American novelist Gore Vidal (1925-2012). The most recent literary adaptation of the topic - "Gods and Legions. A Novel of the Roman Empire" by Michael Curtis Ford - appeared in 2002. ${ }^{10}$ But in the Age of Extremes applause also came from Italian fascists and German National Socialists: Benito Mussolini and Adolf Hitler were enamored

Montesquieu, Sur les causes de la grandeur des Romains (1749), ch. 18: "Ce prince, par sa sagesse, sa constance, son économie, sa conduite, sa valeur, et une suite continuelle d'actions héroiques, rechassa les Barbares"; vgl. De l'esprit des lois (1748), book 24, ch. 10: "Faites pour un moment abstraction des vérités révélées; cherchez dans toute la nature, et vous n'y trouverez pas de plus grand objet que les Antonins; Julian même, Julien (un suffrage ainsi arraché ne me rendra point complice de son apostasie), non, il n'y a point eu après lui de prince plus digne de gouverner les hommes". On Montesquieu, Voltaire and Diderot see Spink, "Julian the Apostate in the Enlightenment" ( $\rightarrow$ i.16); Boch, Apostat ou philosophe? ( $\rightarrow$ i.16), pp. 503-68o and passim.

6 Diderot's views on Julian can be found in no. XLIII of his Pensées philosophiques (1746) and in the article Éclectisme written for volume $\mathrm{v}$ of the famous Encyclopédie ou Dictionnaire raisonné des sciences, des arts et des métiers (1755).

The article "Julien le philosophe" in the Dictionnaire philosophique portatif (1764) is but one out of many texts in which Voltaire praises Julian. For Voltaire's edition of "Contra Galilaeos" see Marcone, "Il Contro i Galilei di Giuliano edito da Voltaire"; for his relation with Frederick II of Prussia see Merveaud, "Voltaire et Frédéric II" ( $\rightarrow$ i.16).

$8 \quad$ Karl Marx/Friedrich Engels, Werke, vol. 30, Berlin-Ost 1964, p. 627.

9 Kojève on Julian: Marcone, "Ierone, Giuliano e la fine della storia" $(\rightarrow$ i.16).

10 For a comprehensive study of Julian's representation in 19th century literature see now Feger, Julian Apostata im 19. Jahrhundert ( $\rightarrow$ i.16). On Eichendorff: Kühlmann, "Romantik der Spätantike?”. On De Vigny: Marcone, “Alfred de Vigny”. On Merezhkovsky: Riikonen, Antike im historischen Roman, pp. 172-81. On Ibsen: Faber/Høibraaten, Ibsens 'Kaiser und Galiläer' ( $\rightarrow$ i.16). On Cavafy: Bowersock, "Julian Poems of C. P. Cavafy" $(\rightarrow$ i.16). Gore Vidal's novel "Julian" was published in 1962 and translated into French in 1966. 
with Julian. ${ }^{11}$ Julian remains a radiant but controversial figure, because he stands for problems that are constantly being renegotiated. (See Stefan Rebenich in Ch. XIII)

Julian's desire to undo the Constantinian Revolution makes his life particularly susceptible to counterfactual considerations: What would have happened if he had not died young on June 26th, $363 \mathrm{AD}$, but had ruled for several decades like his uncle Constantine or his cousin Constantius? There are, of course, no definite answers to questions like this. Yet thought experiments are almost inevitable when one deals with an emperor who was only 32 years old when he died having ruled as Augustus for only a year and a half. A whole host of questions are at stake, which are often hastily lumped together but need to be considered separately. The first question concerns the development of Christian communities under an emperor hostile to them. What impact would the rescinding of material benefits, legal privileges and social rewards that depended on the emperor's favor have had on the social composition, institutional structure, and self-understanding of the Christian communities? Would Christian communities under these conditions have lost many of their members? The second question concerns the extremely heterogeneous set of religious practices and discourses that Christian clerics stigmatized as pagan: How would these cults have developed if Julian had been able to promote and shape them over several decades? Would polytheistic cults have gained a new lease of life and, if so, in what form? ${ }^{12}$ The problem poses itself differently when looking at the Jewish communities: Julian intended to rebuild the temple in Jerusalem which had been destroyed in $70 \mathrm{AD}$. Construction began in the spring of $363 \mathrm{AD}$ under the direction of an imperial official, but was halted before Julian's death due to an earthquake which is now epigraphically attested. The counterfactual assumption that Julian would have had resumed construction if he had returned from the east alive is not entirely far-fetched. But what would he have achieved if he had been able to complete the building? To begin with, there is no evidence on whether Jews at this time still desired to centralize their cult worship at the temple in Jerusalem. It is even harder to imagine how Christian theologians would have reacted to events that would have contradicted the prophecies of the temple's destruction ascribed to Jesus in the Gospels. The only thing that we can say for certain is that the failure of the

For Mussolini see Stefan Rebenich in Ch. XIII. Hitler: Jochmann, Adolf Hitler. Monologe, pp. 96f., 106, 236.

12 On Julian's religious policies see Hans-Ulrich Wiemer in Ch. VII and id., "Neue Priester" $(\rightarrow \mathrm{i} .10)$ (with bibliography). 
temple project in their eyes not only proved the victory of God over Julian, but also the victory of the Church over the Jews. (See Scott Bradbury in Ch. IX)

Julian, however, not only holds fascination as an alternative to the first Christian emperor Constantine. His complex and contradictory nature also stimulates debate. Depending on one's point of view, he appears as a general and a legislator, but also as a writer, philosopher and homo religiosus. Julian is thus unique in that he not only lives on as a Roman emperor, but also as an author of texts which conform to the conventions of Greek literature. To be sure, it is not at all exceptional that for Julian we have Latin texts of a normative character that were written by clerks in a formulaic language in his name and on his behalf. Such texts - so-called constitutions - are handed down for most Late Roman emperors. In most cases, we know of these constitutions because they were included in abridged form in a kind of law book that was compiled on the orders of the emperor Theodosius II and published in 437. The "Codex Theodosianus" is a collection of about 2,50o normative pronouncements of Roman emperors from the period between 312 and $435 \cdot{ }^{13}$

The constitutions of Julian preserved in the "Codex Theodosianus" differ little from those enacted in the name and on behalf of his predecessors and successors. In Julian's case, however, there is also an extensive and diverse corpus of texts in Greek, which can be regarded as ego documents in the narrower sense - as self-formulated testimonies. We have dictated letters to imperial officials and urban communities, but also letters to friends, companions, and confidants. Along with instructions for functionaries, we have effusive letters to the philosophers Maximus and Priscus. To give a few examples: In a letter that Julian wrote to his personal physician Oribasius when, as Caesar (emperor with inferior rank), he was still subordinate to Constantius, he tells of a dream which had caused great anxiety to him until he had been able to find a reassuring interpretation. He then goes on to describe a dangerous conflict he was having with a high civil servant, whom he opposed at the risk of his own life (Letter 14 Bidez $=4$ Wright). Julian discusses childhood memories in a handwritten letter to the orator Euagrius, to whom he donated a country estate (Letter 4 Bidez $=25$ Wright). After the death of Constantius, he wrote himself to his uncle Julianus late at night to defend himself against the accusation that he had wanted to wage war against Constantius. Julian asserts that he was following a command of the gods and that he had hoped Constantius would engage in negotiations (Letter $28 \mathrm{Bidez}=9$ Wright). A few days after the start of the

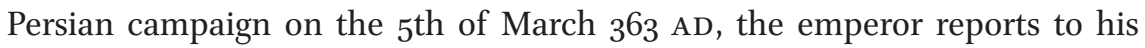

13 The fundamental study of the "Codex Theodosianus" is Matthews, Laying down the Law $(\rightarrow$ i.9). 
"comrade" (hetairos) Libanius his impressions from the advance to the imperial border (Letter $98 \mathrm{Bidez}=58$ Wright $)$.

This corpus, however, also contains texts that were meant to be displayed publicly for wide distribution: There are letters to cities like Alexandria in Egypt, Bostra in today's Jordan, or Edessa in today's eastern Turkey. When a legation of Alexandrians stood up to Julian on behalf of the exiled bishop Athanasius, he gave the Alexandrians a history lesson: In a detailed letter (Letter 111 Bidez $=47$ Wright), the emperor reminded his audience of Alexander the Great, Ptolemy I, and Augustus, and called upon them to return to their ancestral gods Sarapis and Isis. The emperor wrote to the citizens of Bostra after unrest had broken out there (Letter 114 Bidez $=41$ Wright): It was not the congregations that were responsible for the unrest, he asserted, but the Christian clergy. The Christians should chase their bishop out of the city and live in harmony with the devotees of the gods. At the same time, the emperor also admonishes them to renounce violence - people needed to be convinced by reasonable arguments. When Julian was informed that members of the "Arian" church in Edessa, which had received imperial recognition and support under Constantius, had attacked the Valentinian congregation (a small group on the fringe of the Christian spectrum), he wrote to the citizens of that city that he regarded such behavior as contrary to his principles, adding that he had already confiscated the property of the "Arian" congregation as punishment (Letter 115 Bidez $=40$ Wright $)$.

There are few overlaps between the Greek letters and the Latin texts that have found their way into the "Codex Theodosianus". The excerpt of a law passed in Constantinople on the 12th of May 363 affirming the privileges of local doctors (archiatri), contained in the "Codex Theodosianus" (13.3.4), is closely related to a letter on the same topic in Greek, whose beginning and end is missing in the manuscripts (Letter 75 Bidez $=31$ Wright). In the "Codex Theodosianus" (9.17.5) we find an edict that was issued in Antioch on the 12th of February 363 and publicly posted. This edict states that the emperor forbids the burial of the dead during daylight hours. A long letter from Julian in Greek clearly refers to this law, in which he explains the prohibition of burials in daylight at length by philosophical arguments (Letter 136b Bidez $=56$ Wright). Again, the beginning and end of the text are missing, which is why both the addressees and the date are lost. Julian's so-called School Law is highly controversial: Did the emperor actually ban Christian teachers from practicing their profession as Christian authors repeatedly claim? One major reason for the controversy is that Julian's own testimonies are not entirely consistent. A law (13.3.5) on the appointment of teachers, which is preserved in the "Codex Theodosianus", names moral worth but not religious affiliation as a selection 
criterion. Due to abbreviation the addressees of this law are not stated. In a letter in Greek, on the other hand, which is again handed down to us without beginning or end, Julian explains why he considers Christians unsuitable to teach Greek literature (Letter 61c Bidez $=36$ Wright). What is the relationship between these two texts? Does the letter explain the law, or were there two entirely separate measures? Modern scholarship offers widely differing views on this crucial question. (See Heinz-Günther in Ch. VI.)

Besides the more than 60 letters, there are no fewer than eleven writings by Julian that are traditionally classed as speeches. Their literary character differs markedly, however. (See Heinz-Günther Nesselrath in Ch. II.) This corpus includes two panegyrics of the Emperor Constantius and a third on his wife Eusebia. They date from the time when Julian was Caesar in Gaul and thus held inferior rank to Constantius and are unique in that we know of no other speeches dedicated by one emperor to another emperor or empress. As is typical of the panegyric genre, Julian lavishes praise on his cousin Constantius in these speeches. Later, however, when Julian was courting support against Constantius in the impending civil war, he made serious accusations against his cousin, known to us mostly from a pamphlet entitled "Letter to the Athenians". It is impossible to avoid the question of what this discrepancy means for Julian's credibility. Was Julian a master of dissimulation, as his opponents have repeatedly claimed?

In other writings, Julian speaks as a philosopher and theologian. He rejects doctrines that contradict his understanding of education, culture, and religion, and expounds on how to comprehend and worship the gods. Julian responded to the philosopher Themistius, who urged him to be both philosopher and ruler, with a treatise in letter form asserting that a philosophical life was far superior to that of a statesman (bios politikos). He presented his friend Salutius, who had to leave the court of the Gallic Caesar in $358 \mathrm{AD}$, with a long letter cast in the form of a consolatory speech to himself. There are also speeches, however, that the emperor actually recited before a selected audience. In Constantinople, for example, he polemicized in front of a courtly audience against a philosopher named Heraclius, who saw himself as a cynic, and in another speech he explained the philosophical core of cynicism. In hymn-like treatises on the Mother of the gods and the Sun god, the emperor interpreted the rituals and myths associated with these deities within the framework of a theology inspired by Neoplatonism. While preparing the Persian campaign the emperor began to write a polemical treatise against the "Galileans" (meaning Christians) divided into three books, which survives in extensive fragments; from these Julian shows himself an expert in Christian biblical exegesis, ethics and dogmatics. (See Christoph Riedweg in Ch. VIII.) 
In many of these texts Julian frankly speaks of himself. In his speech against the cynic Heraclius, Julian uses a kind of 'model myth' to explain how a narrative about the gods should be designed. He takes himself as an example: $\mathrm{He}$ had been instructed by the gods to save the Imperium Romanum, which had fallen into hopeless confusion under the rule of Constantine's sons. In a satire, the so-called "Caesares", the emperor subjects his predecessors, beginning with Caesar, to a critical examination, and adding Alexander the Great as the most successful conqueror of all times. Julian puts speeches in the mouths of those who passed the first round, and in the end, declares Marcus Aurelius the winner, while strongly condemning Constantine (along with his sons) as a slave of lust and incontinence who had deserted the gods because only Jesus was prepared to cleanse him of his many sins. He portrays himself as the embodiment of all virtues proper to an emperor: wisdom, moderation, justice, and bravery - the perfect combination of Marcus Aurelius and Alexander. Finally, Julian also left behind a peculiar text known as "Misopogon" (beard-hater). The ironic and self-mocking text was made public in Antioch by being posted like an edict. In this text, the emperor feigns acceptance of the accusations raised against him in Antioch. He professes that the Antiochenes were right to have rejected him, namely because his uncultured nature was not compatible with their refined lifestyle: He did not like to go to the theatre and he hated chariot racing; he slept and ate little; he constantly worshipped the gods through prayers and sacrifices. No other Roman emperor has ever publicly exposed himself in this way.

To be sure, every author provides information about himself or herself in one way or another. Julian, however, again and again makes himself the subject of his writings: He talks about his childhood and youth, his relationship with his half-brother Gallus, his cousin Constantius and his cousin's wife Eusebia; he describes his dreams and visions, motivations and goals, fears and hopes. We learn about his tutor Mardonius, his love of books and his dislike of theatre and the circus. Many Roman emperors can only be grasped through their public actions. It is different with Julian: Many texts are extant in which he explains and justifies his actions. Modern researchers have often been tempted to take these statements at face value by simply repeating what Julian says about himself. ${ }^{14}$ This approach has come under justified criticism, since claims

14 E.g. Geffcken, Kaiser Julianus ( $\rightarrow$ i.2), p. 127: "Few ancient personalities allow us to read into their souls as he does; we can often follow his thought processes and feelings hour by hour, follow the various changes of his mood. His life plays out with unprecedented turbulence. He is always engaged in the most diverse activities. From the days of his childhood, he was devoted to ideals, enthusiastic about the gods and their servants, without any hint of sensuality; he was fiercely committed to his friends" ("Wenige antike 
made about one's self should never be accepted without verification. How people interpret and present themselves depends on many factors, not least on the aims they pursue in communicating with others. When it comes to an emperor, the question of intent is critical, since nothing that an emperor does or says is significant to him alone. Nevertheless, the large number of ego-documents adds dimensions to Julian's image that are missing in most other personalities of the Greek-Roman world: Inner mental experiences, reading habits and interests, retrospective interpretations of one's youth, communications with confidants, habits and strategies of argumentation and articulating ideas.

The abundance of autobiographical material is one reason why Julian has been presented over and over again in biographical form. But the study of Julian also holds great appeal because there is, by ancient standards, an unusually rich dossier of sources for his life and reign. Julian can be found reflected in a kaleidoscope of diverse texts. The reports on Julian's wars in Gaul - analyzed by Peter Heather in Ch. III - are surpassed in density and information content only by Caesar's self-portrait in the "Gallic War". In Julian's case, however, the self-portrait of the victorious general (in Julian's "Letter to the Athenians") can be compared to the representation by a well-informed contemporary, Ammianus Marcellinus, who put Julian front and centre in books 15-25 of his historical work. The reports on Julian's Persian War - analyzed by Neil McLynn in Ch. $\mathrm{x}$ - enable us to follow the path of the Roman army over long distances from place to place and sometimes from day to day; for no other military enterprise of Late Antiquity have so many details been handed down to us. The Greek sophist Libanius was the first to write a circumstantial, if rhetorical account of the campaign (Oration 18); it was completed only a few years after the events $(365$ ?) and is based upon the material provided to him by participants in the war. Ammianus Marcellinus, who dedicated three books of his historical work to Julian's Persian campaign, himself took part in the campaign. The historical work of the sophist Eunapius which was published for the first time around 380 (or so it seems) is lost in the Greek original but for a few fragments. The text was still extant, however, around 500 when Zosimus used it for his depiction of Julian, which has been preserved. While Eunapius seems never to have met Julian, he was able to draw on records from Oribasius, the personal physician of Julian, for the Persian campaign.

Persönlichkeiten gestatten uns, so in ihrer Seele zu lesen gleich ihm, wir können nicht selten sein Denken und Fühlen von Stunde zu Stunde begleiten, den vielfachen Wechsel der Stimmungen verfolgen, sein Leben spielt sich mit beispielloser Hochspannung ab. Immer ist er in Tätigkeit der verschiedensten Art, seit den Tagen der Kindheit dem Ideellen schwärmerisch zugewandt, ohne jede Regung der Sinnlichkeit, sein Herz den Freunden stürmisch schenkend, begeistert für die Götter und ihre Diener"). 
Julian provoked literary responses already during his lifetime. (See Arnaldo Marcone in Ch. XI.) No less than half a dozen speeches dedicated to the emperor in the year and a half of his sole reign have been preserved. The Latin eulogy of Claudius Mamertinus on Julian was held on January 1st $362 \mathrm{AD}$ in Constantinople before high-ranking military officers and senators; the speaker was a praetorian prefect and thus one of the highest civilian officials of the empire. In the same place a few weeks later the Greek sophist Himerius gave a speech in the presence of the emperor, whose text survives (Oration 43). In the summer of $362 \mathrm{AD}$, the sophist Libanius greeted Julian in Syrian Antioch with a eulogy that is still extant (Oration 13). When Julian entered his third consulate on January 1st $363 \mathrm{AD}$, Libanius was again one of the orators. This speech is also preserved (Oration 12). In addition, there are two speeches which Libanius addressed to the emperor because he wanted to win him over for a cause: The plea in defence of the zealous pagan Aristophanes (Oration 14) was verifiably successful. The speech, on the other hand, with which Libanius hoped to convince Julian to settle his grudge against the Antiochenes (Oration 15) was not written until the emperor had already departed for the Persian campaign and probably did not reach him before his death. Around the same time, Libanius wrote a speech in which he admonished his fellow citizens to placate the emperor by adjusting their behaviour to his wishes (Oration 16).

Julian's early death on the Persian campaign triggered violent reactions. On the one hand, Christian authors rejoiced, for they saw in Julian's death proof of the power of their God. (See Peter van Nuffelen in Ch. XII.) Julian's followers, on the other hand, were on the defensive because they had to explain - to themselves and to others - how it was possible that the gods let the emperor who wanted to revive their cult die so young. The style of the debate was characterized by polemics and apology. The accounts of Julian therefore not only vary in many details but also offer widely differing interpretations and evaluations. They also differ in their literary forms and they originate from very different cultural milieus. A few years after Julian's death (in 365?), Libanius, a committed pagan and friend of Julian's, wrote a detailed biography of the emperor in the form of a Greek funeral speech (Oration 18). Libanius depicted the emperor not only as a ruler without fault or blame, but even as a veritable saint, elevated to the gods after his death. Once he was gone, the highest cultural values - the worship of the gods, Greek education, and the cities as centres of civilized life - were doomed to extinction. On the other hand, the Christian theologian Gregory of Nazianzus pilloried Julian in two invectives (Orations $4+5$ ) which were written almost simultaneously (364?) as a lying and insidious persecutor of Christians, who had challenged God and received just punishment. Gregory shared with Libanius a belief in the unique value of 
Greek education and literature: thus none of Julian's legal measures agitated him more than the so-called School Law which, on his interpretation, excluded Christians from teaching Greek literature. ${ }^{15}$ The Syrian theologian Ephrem, on the other hand, whose home town of Nisibis fell under Persian rule after the failure of Julian's Persian campaign, had little regard for Greek education. He used Syrian, his native tongue, for his four so-called hymns about Julian each of which is divided into go verses. In these verses, Ephrem meditated on the course of Roman history since Constantine. Why did God let the pagan Julian follow the Christian Constantius?

That the cross when it had set out had not conquered everything was not because it was not able to conquer, for it is victorious, but, so that a pit might be dug for the wicked man, who set out with his diviners to the East, when he had set out and was wounded, it was seen by the discerning that the war had waited for him so that he might be put to shame.16

For Ephrem, Julian's failure meant not only the defeat of the Gentiles, but also of the Jews, who to him were followers of Julian and allies of the Gentiles. The Syrian theologian interprets the loss of his hometown to the Persians as a punishment for cooperation with the pagan emperor. Accordingly, both the Persian flag that flew over Nisibis and the corpse of Julian, which he had also seen with his own eyes, symbolized Christ's victory over the pagans. Julian's attempt to rebuild the temple in Jerusalem contradicted God's plan of salvation and therefore had to fail. Ephrem and many other Christian theologians viewed the destroyed temple as the symbol of the victory of the Christian church over the Jews. ${ }^{17}$

\section{Assumptions and Directions in Modern Scholarship on Julian}

In the Latin and Byzantine Middle Ages Julian was almost without exception condemned as an enemy of God and persecutor of Christians. This view seemed confirmed by fictitious texts that tell of the death of staunch Christians under the rule of Julian. Many places boasted of possessing the bones of

\footnotetext{
15 On Gregory and Julian see Moreschini, "Giuliano nelle due invective di Gregorio Nazianzeno" ( $\rightarrow$ iii.8); Elm, Sons of Hellenism $(\rightarrow$ iii.8) and Peter van Nuffelen in Ch. XII.

16 Ephrem, Hymns against Julian 3, 7.

17 For a literary study of Ephrem's Hymns against Julian see Griffith, "Ephraem the Syrian's Hymns against Julian” ( $\rightarrow$ iii.4). See further Peter van Nuffelen in Ch. XII.
} 
martyrs, in whole or in part, who had sacrificed their lives for their Christian faith under Julian..$^{18}$ This sweeping condemnation was not questioned until the 16th century when religious wars were fought in many parts of Europe with unforgiving brutality. This experience aroused a longing for tolerance and shook the belief that only orthodox Christians could be virtuous people. In 1566, the French jurist and philosopher Jean Bodin declared in a historical treatise that Julian could not be judged fairly if he were merely regarded as an apostate. His activity as legislator and general also needed consideration. In this respect he had, according to Bodin, shown all the virtues required of a ruler. ${ }^{19}$ Bodin based this judgement on the authority of the pagan historian Ammianus Marcellinus, whose work had by this time already been printed; no less than seven editions appeared between 1517 and 1552. Julian's letters and speeches became available in print soon thereafter: Pierre Martin edited the Greek text of the letters (with Latin translation) in Paris in 1566. In 1630, Denis Petau published his more complete edition at the same location. He was followed by Ezechiel Spanheim whose edition came out in Leipzig in 1696. As both editions contained extensive commentaries in addition to Latin translations, they made it possible to compare the statements of the ecclesiastical writers not only with the account of Ammianus, but also with Julian's own testimonies.

The first modern biography of Julian appeared in Paris in 1735 . The author, Jean Philippe René de La Blét(t)erie (1696-1772), was a Catholic priest, but adhered to the Jansenist faith, which had been condemned as heretical in 1713. La Bléterie was by no means anti-clerical or even anti-Christian; he presented Julian's life as an object lesson on the necessary failure of a ruler who had turned away from God. But La Blétérie followed the methodical rules of critical

18 On Julian as a persecutor see Teitler, Last Pagan Emperor $(\rightarrow$ i.1o) and Peter van Nuffelen in Ch. XII. The image of Julian in the Byzantine World is studied by Trovato, Giuliano l'Apostata nel Medioevo bizantino $(\rightarrow \mathrm{i} .16)$.

19 Bodin, Methodus, p. 139: "at ecclesiastici fere scriptores cum de adversariis nostrae religionis scriberent, tantis odiis exarserunt, ut non modo laudes eorum obruere, verum etiam omnibus contumeliis lacerare conarentur. Argumento sit Julianus Augustus, is qui transfuga usurpatur, qui tametsi capitali odio ac suppliciis omnibus dignus esset, quae tamen ab eo praeclare gesta sunt, historiam scribentem non decuit praeterire, quod nostri fecerunt. In quo certe Ammiani Marcellini candorem ac studium inquirendae veritatis imitari debuissent. Is enim principum virtutes ac vitia, ut optimus quisque scriptor, summa fide notavit. Julianum accusat quod religionem Christianam absolutam ac simplicem (sic enim loquitur) anili superstitione confudisset: quod Christianis literas crudeliter ademisset: quod Palatinos Constantii comites occidi iussiset; ejusdem tamen virtutes egregias oratione singulari commendavit: summam temperantiam, fortitudinem, continentiam, sapientiae studium, ac justitiam opinione majorem, quae gravisssimis exemplis ac testimoniis confirmat". 
historical research, which had long proved their worth as a weapon in the struggle against the Protestants: La Bléterie drew on all the sources available to him and compared their statements carefully; he also made extensive use of Julian's own writings. At the same time, he tried to reach a differentiated judgement about Julian's personality and government, even though he took pains to stress that every one of Julian's virtues was marred by some flaw. ${ }^{20}$ La Bléterie's biography of Julian caused a sensation and was soon translated into English (1746) and German (1752). In 1748, La Bléterie published a sequel: a book on Jovian, Julian's successor, to which he added French translations of some of Julian's writings and selected letters. ${ }^{21}$

The enlightened historian Edward Gibbon (1737-1794) measured Roman emperors by the maxims of philosophical ethics and politics. Gibbon had been fascinated by Julian since his youth. In volumes 2 and 3 of his famous "History of the Decline and Fall of the Roman Empire" (1781), he dedicated several chapters to him and repeatedly heaped praise on him; he could state that even "religious faction" had to acknowledge that Julian loved his country and rightfully deserved to rule the world. ${ }^{22}$ At the same time, however, Gibbon was put off by Julian's religiosity, which he saw as "superstition", and doubted that Julian's religious policy was for the good of his subjects. At one point, he bluntly states that the emperor would have plunged the empire into civil war if he had consistently pursued his goal of annihilating Christianity. 23

In the 19th century, historical research became an academic discipline throughout Western Europe, committed not only to critical analysis of the sources as an indispensable tool for establishing historical facts but also to impartiality as a necessary precondition of historical interpretation which claims

20 Bléterie, Vie de l'empereur Julien ( $\rightarrow$ i.16), p. 15: "Je ne crois point que le bien que j'en ai dit doive peiner les consciences les plus délicates. Ce seroit trop priser les vertus humaines, que de se persuader, contre l'experience de tous les siècles, que Dieu ne les donne jamais à ses plus grands ennemis. J'ai réprésenté celles de Julien dans le vrai, c'est à dire, toujours defigurées par quelque défaut: et d'ailleurs il les a tournées contre leur auteur; ce qui doit nous les rendre odieuses".

21 Renaissance re-discovery of Ammianus: Nesselrath, "Wiederentdeckung von Julian Apostata" ( $\rightarrow$ i.16). Early editions of Julian's writings: Prato, "Storia del testo e delle edizioni di Giuliano Imperatore" $(\rightarrow$ ii.1).

22 Gibbon, Decline and Fall, ch. 22 (Vol. 1, p. 863 Womersley): "Even faction, and religious faction, was constrained to acknowledge the superiority of his genius in peace as well as in war, and to confess, with a sigh, that the apostate Julian was a lover of his country, and that he deserved the empire of the world".

23 The citation is from Gibbon, Decline and Fall, ch. 23 (Vol. 1, p. 908 Womersley): "If we seriously reflect on the strength and spirit of the church, we shall be convinced, that, before the emperor could have exstinguished the religion of Christ, he must have involved his country in the horrors of a civil war". Cp. Bowersock, "Gibbon and Julian". 
objectivity. The methodological maxim was that every historical figure needed to be interpreted in terms of his (or her) own time. When dealing with the past, historians were expected to rise above their particular situation in society and to efface their personal beliefs, including their faith and confession. Since 19thcentury Europe was largely Christian, it was an intellectual challenge to apply these principles to an emperor who had turned against Christianity. But Julian also invited scholars to test the new principles because he had denied the compatibility of ancient education and Christianity. In his view, Christians were not capable of teaching the classical literature of the Greeks. This ran contrary to common assumptions since 'classical studies' were regarded throughout 19th century Europe as the foundation of all higher education. The teachers, moreover, were almost always baptized Christians, whatever their denomination might be. Coming to terms with Julian thus meant facing a dilemma: On the one hand, a Roman emperor who wanted to be a Greek philosopher corresponded to the 19th-century ideal, even if the form classical culture had taken by the time of Julian was deemed to be more or less decadent. On the other hand, Julian's attempt to pit traditional classical education against Christianity contradicted the deep-seated conviction that in the present they were harmoniously united.

In Germany, the challenge to understand Julian in terms of his own time was taken up first and foremost by Protestant historians. For them, empathy with Julian was easier because they were themselves suspicious of or openly hostile to Church dogmatics and discipline. In 1812, the Church historian and theologian August Neander (1789-1850), a convert from Judaism to Lutheran Christianity, made the first attempt to come to terms with Julian. Neander described Julian as a righteous and religious person who had never reached a deeper understanding of the gospel of Jesus Christ. ${ }^{24}$ Neander was followed in the second half of the century by the grammar school teacher (Gymnasialprofessor) Alphons Mücke who in 1867 published a study of Julian's life and reign in two volumes. Mücke treated Julian primarily as a general, but also as a statesman, writer, and human being. In 1877, the Protestant theologian Friedrich Rode issued a monograph "Geschichte der Reaction Kaiser Julians gegen die christliche Kirche" (History of the Emperor Julian's Reaction against the Christian Church) which had been submitted as a dissertation in Jena. Both works are characterized by a careful analysis and meticulous documentation

24 Neander's Kayser Julianus $\left(\rightarrow\right.$ i.16) was translated into English in $185^{\circ}$. A revised edition in German came out in 1867 . 
of the sources; through a programmatic commitment to objectivity they claim to present Julian according to modern principles of historical research. ${ }^{25}$

Among Roman Catholics, the charge that Julian was an enemy of God and persecutor of Christians persisted longer. In 1817, the French scholar Étienne Jondot (1770-1834) in the spirit of the Bourbon Restoration called to account both Julian and the Enlightenment philosophers who had defended him. In his eyes, Julian was a precursor to Napoleon Bonaparte. ${ }^{26}$ In 1855 , the Viennese grammar school teacher Johann Evangelista Auer repeated in his own words the invectives of the church fathers against Julian. ${ }^{27}$ By the second half of the 19th century, however, the new understanding of historical research also came to prevail among Catholic scholars. An evaluation of Julian's apostasy from the true religion was now considered to be the task of theologians. Historians merely needed to describe and explain it. The French archaeologist and historian Paul Allard (1841-1916), an intransigent Catholic, published a three-volume biography of Julian in Paris at the turn of the century, which was reprinted several times. Allard exhibited all the testimonies for Julian's personality and government to the reader, even those which he himself considered utterly worthless as historical evidence. Julian's apostasy was, in his view, understandable (if inexcusable) in so far as he only knew Christianity in a form that was distorted by "Arian heresy". Allard contemplated whether Julian had suffered from a mental illness, as he believed that the emperor had behaved like a lunatic during the second half of his sole reign. ${ }^{28}$ Around 1900, Julian became an object of study in psychopathology and for some scholars remains so to this day. ${ }^{29}$

Mücke, Flavius Claudius Julianus ( $\rightarrow$ i.16); Rode, Reaction Kaiser Julians ( $\rightarrow$ i.10). Jondot, Histoire de l'empereur Julien.

Auer, Kaiser Julian der Abtrünnige.

Allard, Julien l'Apostat ( $\rightarrow$ i.2). The book was reprinted in Rome in 1972 as vol. 102 of the series "Studia historica".

In 1914, the German philologist Johannes Geffcken spoke against the attempt to offer a psychopathological interpretation of Julian in Kaiser Julianus $(\rightarrow \mathrm{i} .2)$, p. viıI: "The modern observer of Julian might feel the need to occasionally describe the nature of this human monarch as that of a 'neurotic man.' Nevertheless, we generally have not yet come to the conclusion in historical science - thank goodness - that the phenomena of an historical life can only be observed from the pathological point of view, nor do we lock up the historical individual in the solitary cell of the general hospital. We still seek to explain the individual in an unsanitized way in terms of his own person and his time ("Der moderne Betrachter Julians könnte wohl hie und da das Bedürfnis empfinden, das Wesen dieses Monarchen als das eines 'Nervenmenschen' zu bezeichnen. Aber noch sind wir in der historischen Wissenschaft gottlob noch nicht allgemein dahin gekommen, die Erscheinungen des geschichtlichen Lebens nur vom pathologischen Gesichtspunkt aus zu beobachten, noch sperren wir das historische Individuum nicht in der Einzelzelle des 
The Italian politician and journalist Gaetano Negri (1838-1902) almost simultaneously (1901) published a biography of Julian constructed on completely different premises: the belief in cultural progress through science. Negri considered Julian an admirable figure who was passionate, generous, and heroic, but at the same time a "uomo squilibrato": a personality combining a rampant and muddled imagination with pedantry. His worst flaw was his irrational religiosity, his "superstition" and "mysticism". ${ }^{30}$ Julian's turn against Christianity was for the liberal Catholic Negri an understandable (if ultimately wrongheaded) reaction to the decadence and corruption of the post-Constantinian church. In order to save ancient culture from destruction, the emperor vainly tried to transform ancient polytheism into a dogmatic religion that was able to counterbalance Christianity. According to Negri it would be unfair to blame Julian for not tolerating the Christians as teachers in public schools as they fought against polytheism which he considered to be the religious basis of the state. Julian's religious policies were doomed to failure, however, because the Christian message, even in its depraved form, had more to offer the masses than Julian's Neoplatonic polytheism. ${ }^{31}$

In the German Empire, it was customary to regard Julian as a tragic figure. The emperor had pursued honorable goals which were ultimately unattainable because Christianity could no longer be suppressed, despite all its temporary shortcomings. The Protestant theologian David Friedrich Strauss (1808-1874) thus referred to Julian as "a romantic on the throne of the Caesars". 32 German scholars of the Wilhelmine period tended to make a strict distinction between Julian's deeds and aims, on the one hand, and his character on the other. Even those who rejected Julian's religious policy tended to attribute to him an 'honorable character' and 'lofty ideals'. In 19o1, the Protestant church historian Adolf (von) Harnack (1879-1930) felt compelled to state that his admiration for Julian's virtues and education had often made him forget that "his policy had been quixotic in its aims, even harmful in all respects to the common good". ${ }^{33}$ Julian's letters received praise as the unvarnished expression of a complex personality striving for moral perfection, while his philosophical

allgemeinen Krankenhauses ein, noch suchen wir es ohne Hygiene aus sich selbst und seiner Zeit zu erklären"). On the psychopathological approach to Julian see also the critical remarks of Bouffartigue, "L'état mental de l'empereur Julien" $(\rightarrow \mathrm{i} .4)$. For Julian as a "uomo squilibrato" see Negri, Imperatore Giuliano ( $\rightarrow$ i.2), p. 399f. On Negri's portrait of Julian see Marcone, "Gaetano Negri" ( $\rightarrow$ i.16).

31 Julian's School Law: Negri, Imperatore Giuliano ( $\rightarrow$ i.2), pp. 321-47. Religious policy: ibid., pp. 498-519.

Strauss on Julian: Kühlmann, "Romantik der Spätantike”; Kinzig, "Kaiser, König, Ketzer" $(\rightarrow \mathrm{i} .16)$. 
writings were considered sterile and scholastic. It was commonplace to stress that Julian had led an exemplary private life and had restlessly worked for the common good. It was also agreed that the emperor had seen himself as the first servant of the Roman state, as every good ruler should. As a military commander Julian also gained recognition across denominations. Even when his abilities as a strategist were cast into doubt, hardly anyone denied his personal prowess. In Wilhelmine Germany, Julian was viewed as emperor, writer, and soldier. ${ }^{34}$

Since the beginnings of modern scholarship, Julian's image greatly depended on the assessment of his character. Biography thus seemed to be the natural way of approaching his reign. In fact, few figures of antiquity have been chosen for biographical treatment as frequently as Julian. The classic biography of Julian by the Belgian scholar Joseph Bidez (1867-1945) appeared in French in 1930, was translated into German in 1940 and into Italian in 2004. It was written by an outstanding authority on the intellectual and religious history of Late Antiquity and is still worth reading. With considerable literary talent, the liberal agnostic Bidez portrayed Julian as "a unique mixture of reckless brazenness and thoughtful calculation". Bidez wove Julian's own testimonies into a narrative frame based on the contemporary historiographer Ammianus Marcellinus, thus allowing the reader to share in the inner experiences of the protagonist. In this account, Julian appears to be predisposed to "mysticism"; he turns away from Christianity as a result of emotional experiences that are beyond rational analysis. Bidez was by no means blind to the shortcomings of his protagonist. He stressed that the emperor quickly renounced the principle of tolerance that he had proclaimed at the beginning of his reign and launched an open campaign against Christianity. For Bidez, the attempt to renew paganism was a utopian conceit based on a complete misunderstanding of the historical situation. In spite of all this, Bidez approved of Julian as a personality of considerable historical significance:

What makes him stand out and constitutes his claim to greatness is neither his leading idea nor the project he pursued; this is due to the high

34 Characteristic examples are Geffcken's biographical monograph Kaiser Julianus $(\rightarrow \mathrm{i} .2)$, published in 1914, and the article "Iulianos (Apostata)" in Pauly-Wissowa's Realencyclopädie, written by Emil von Borries and published in 1917. The view that Julian was above all emperor and soldier was not, however, peculiar to Wilhelmine historians. It also characterizes the popular monograph Giuliano l'Apostata $(\rightarrow \mathrm{i} .2)$ by the Italian historian Corrado Barbagallo (1877-1952), published in 1912 and reprinted in 1924 and 1940. Barbagallo later wrote the article "Iulianus" in the Dizionario epigrafico di antichità romane, vol. 4, Spoleto 1930, pp. 173-209. 
qualities of his intelligence and his character. It is due to his vigour, his enthusiasm and the sincerity of his soul; it is also due to the prodigious effort of his will. He was determined, obstinate, dauntless [...] Julian was defeated: history has made him an object of derision; his experiment has been attacked and denigrated. Does this justify denying to him the respect to which all sincere beliefs are entitled? ${ }^{35}$

Bidez's biography of Julian immediately won international acclaim as a work that successfully combined scholarship and literary imagination. It is still considered a standard work to this day. After the appearance of this masterpiece, the output of Julian biographies declined sharply. Nevertheless, psychological approaches to Julian predominated until the 1980s. This applies even to the sober and well-balanced biography by the British Byzantinist Robert Browning (1914-1997), who in 1976 once again saw in Julian "a tragic figure, a man of infinite promise, cut off before his prime". ${ }^{36}$ The Greek historian Polymnia Athanassiadi(-Fowden) approached Julian with a degree of empathy bordering on enthusiasm in an "intellectual biography" based on an Oxford dissertation and published in 1981. The declared aim of this study was to unveil the inner secrets of Julian's 'Hellenic' soul. ${ }^{37}$ In 1986, the French historian of philosophy Lucien Jerphagnon (1921-2011) again used a biographical narrative to depict Julian. ${ }^{38}$ In the 1970s, however, Julian underwent a radical revaluation that recast the philosophical idealist as an unscrupulous fanatic. But this criticism of older research was itself based on a psychogram of Julian and was therefore most convincingly articulated in the form of a biography. The American historian Glen Bowersock opened his biography of Julian (1978) with a chapter on the emperor's personality:

35 Bidez, Vie de l'empereur Julien ( $\rightarrow$ i.2), p. 350: "Ce qui le distingue et fait sa grandeur, ce n'est l'idée directrice ni l'entreprise qu'il conçut; ce sont les hautes qualités de son intelligence et de son caractère. C'est l'ardeur, l'enthousiasme et la sincérité de sa foi; c'est aussi l'effort prodigieux de sa volonté. Il fut décidé, obstiné, intrépide [...] Julien a succombé: l'histoire l'a tourné en dérision, et sa tentative a été attaquée et calomniée. Faut-il pour cela lui refuser les égards auxquels ont droit les convictions sincères?". For information on Bidez, see Severyns, "Notice sur Joseph Bidez".

36 Browning, The Emperor Julian $(\rightarrow$ i.2), p. xii. Browning's book was sympathetically reviewed by Peter Brown ("The Last Pagan Emperor").

37 Athanassiadi(-Fowden), Julian and Hellenism $(\rightarrow$ i.2). The book came out in a second edition in 1992; it has been translated into Italian (1984) and Modern Greek (2001).

38 Jerphagnon, Julien dit l'Apostat. The second edition (Paris 2008) has a preface by Paul Veyne. 
Julian clearly believed in his own destiny. His courage and fortitude were not illusory. His nearness to the gods strengthened his conviction; and his austere style of life, with its isolation from normal human contacts, equipped him for the single-minded pursuit of his goals. He can easily take his place in the class of the ascetic revolutionaries, which included in later times such other isolated and self-denying activists as Lenin and Mao Tse-Tung. ${ }^{39}$

This new image of Julian met with great approval, even if the comparison with Lenin and Mao Tse-Tung was thought to be over the top. It was also on the pulse of the times, since the historiographical cult of great men was now widely regarded as suspect. In the meantime, critical judgements have come to prevail in academic historiography. For instance, the most recent Julian biographies in German, written by the historians Klaus Bringmann (2004) and Klaus Rosen (2006), also discuss their protagonist from an overt distance. In this respect, the 1970s marked a turning point for Julian studies. However, since the new Julian image was based no less than the one it had replaced on a psychogram of the emperor, it remained within the biographical framework of interpretation. ${ }^{40}$

Efforts to identify an alternative to biography as a form of representation were made from the beginning of the 2oth century onwards by scholars convinced that Julian had been an important statesman and reformer. They thought it necessary to examine his activities as emperor, in particular those as legislator and judge. For them, historical judgment had first and foremost to be based on the interpretation of normative texts and the analysis of concrete decisions and actions. In 1911, Wilhelm Ensslin submitted a dissertation with the programmatic title "Kaiser Julians Gesetzgebungswerk und Reichsverwaltung" (The emperor Julian's Legislative Work and Imperial Administration) to the university of Strasbourg (then in the German empire), although because of the First World War it did not appear in print until 1922. Ensslin (1885-1967) who was later to become one of the most respected experts in the history of the Late Roman Empire passed an extremely favourable judgment on Julian's reign which in his view was "among the most splendid that the Roman Empire had ever seen":

39 Bowersock, Julian the Apostate, p. 2o. Paschoud, "Trois livres récents" hailed the book soon after its publication as a successful exposition of the modern image of Julian. John Matthews ("The New Traditionalist"), on the other hand, was quick to point out conceptual shortcomings. The book was three decades later translated into French (2008).

40 Rosen, Julian; Bringmann, Kaiser Julian. On the biographical approach to Julian see also Bouffartigue, "Julien entre biographie et analyse historique". 
Three things left their mark on his short reign; first [...] his vigorous protection of the empire's borders, second, a prudent and just imperial administration, and, finally, his religious policy. It was the latter which, in the wake of his adversaries' victories, caused his name to be branded in the annals of history with the epithet Apostata and made his period of government appear as a nadir. Yet Julian's legislation and imperial administration has shown us the opposite. ${ }^{41}$

This view resonated immediately with historians who studied the Imperium Romanum as a political organism and mostly were indifferent to religion. The German-Austrian historian Ernst Stein (1891-1945), like Ensslin a leading expert on the late Roman state, offered extremely positive testimony on Julian's domestic policies. In his "History of the Late Roman Empire" (Geschichte des Spätrömischen Reiches), published in German in 1928 and translated into French in 1959, Stein admitted that Julian had made mistakes even outside the realm of religious policy. According to Stein, Julian did not sufficiently safeguard the trials of former functionaries of Constantius against external influences. By and large, however, Julian's reign was for Stein "one of the most salutary that the Roman Empire has ever experienced". According to Stein, Julian had reduced government expenditure by cutting back on court staff and the number of imperial commissioners (agentes in rebus); at the same time, he had distributed the tax burden more evenly. Stein noted further that Julian had strengthened the financial power of the cities and had vigorously countered corruption in the governmental machinery. ${ }^{42}$ In a 1930 treatise on Julian's legislative and administrative activities, the Italian historian Roberto Andreotti (1908-1989) elevated this praise of the emperor to a veritable panegyric: Julian, we are told, was the rare case of a ruler in whom theory and practice were in perfect harmony. He had "brought into being that type of the best first citizen (princeps), who expresses the ideal of Romanitas to the highest degree"; in

41 Ensslin, "Julians Gesetzgebungswerk" ( $\rightarrow$ i.8), p. 19o: "Drei Dinge sind es, die seiner kurzen Regierung ihren Stempel aufgedrückt haben; zuerst [...] sein tatkräftiger Schutz für die Reichsgrenzen, zum anderen eine sorgfältige, gerechte Reichsverwaltung und endlich seine Religionspolitik. Diese war es, die in der Folgezeit nach dem Siege seiner Gegner seinem Namen in der Geschichte den brandmarkenden Beinamen Apostata hinzugefügt hat und seine Regierung als die Zeit großen Tiefstands erscheinen ließ. Doch zeigte uns Julians Gesetzgebung und Reichsverwaltung das Gegenteil davon".

42 Stein, Geschichte des spätrömischen Reiches, p. 26of. Soon after his book's publication, Ernst Stein converted from the Protestant to the Catholic faith. The French translation came out after his death in 1945 . 
Julian, the Imperium Romanum had virtually embodied itself as a normative order. ${ }^{43}$

The British historian A.H.M. Jones (1904-1970) was averse to rhetorical exuberance. But he, too, paid high praise to Julian in his extensive social, economic, and administrative history of the late Roman Empire (1964), which to this day remains essential reading for anyone studying the period. Like Ensslin and Stein, he saw Julian principally as a far-sighted reformer:

In more ways than one Julian attempted to stem the tide, and to put things back as they had been before the reign of the uncle whose memory he loathed. He swept away the ostentatious splendor of the court and drastically pruned the palatine services. He endeavored to reduce the burden of taxation and to revivify the cities. Above all he strove to restore the worship of the ancient gods. His secular reforms seem to have been effective for the time being, though few had any lasting results. How successful his pagan revival was during the eighteen months that it lasted it is impossible to say. ${ }^{44}$

Reducing government spending, decreasing the tax burden on the subjects, fighting bureaucracy and corruption, and strengthening urban communities - these are the leitmotifs that permeate earlier Julian research through the 1970s. Julian was seen as the great exception among the emperors of the 4th century AD: He recognized what the Imperium Romanum was suffering from and tried to put an end to it. This image was influenced by the idea that the Imperium Romanum under Constantine the Great and his sons had developed into a 'coercive state' which had demoted the formerly autonomous cities into executive organs of its arbitrary will and ruined the local upper classes through excessive taxation. A bureaucratic juggernaut had in this view destroyed the social foundations of ancient culture. Julian tried to reverse this development by advocating the autonomy of cities. Corroborative testimonies were often invoked from Julian himself and his admirers: When Julian adopted a series of measures in favor of individual provinces or cities soon after the beginning of his autocracy this was seen as an expression of a political program that was fundamentally different from the course taken by his predecessors. The same program of reform was also found in Libanius, who never tired of praising the

43 Andreotti, "L'opera legislativa" ( $\rightarrow$ i.8), p. 272f. (p. 178 of the German translation). Andreotti expressed similar views in his biography of Julian, which was published six years later: Il regno dell'imperatore Giuliano $(\rightarrow \mathrm{i} .2)$, Bologna 1936. 
emperor as a friend and champion of the cities (philopolis) while accusing his predecessor Constantius of almost ruining them. ${ }^{45}$

Recent research has fundamentally revised this reading of history in two respects: On the one hand, the idea that the late Roman state had regulated all areas of social life has been abandoned today. Far from trying to control and shape every area of society, the late Roman state extended its claim to regulation only to those areas which were indispensable for its own functioning. The state collected taxes from (almost) all free inhabitants of the empire and obliged them to provide services for the court, the military, and the administration; the state also attempted to restrict the mobility of groups of people who were responsible for public services. But even in Late Antiquity the state had neither the means nor the desire to direct the economy or reform the social order. In addition, the late Roman state was always dependent on the assistance of local elites for the enforcement of legislative measures, since the lowest level of administration was always the cities. The term 'coercive state' has therefore almost completely disappeared from the discourse of historical scholarship (although not from legal history). ${ }^{46}$

On the other hand, the idea that cities had, in the 4th century, declined both as settlements and communities in many parts of the empire has not withstood scrutiny. As research over the last decades has convincingly shown, the network of cities was quite stable in the majority of the provinces, namely in Italy, North Africa, Egypt, Syria, and Asia Minor. The monumental building stock had been preserved and municipal institutions functioned. If the curiales - the members of the city councils (curiae) - around the middle of the 4th century often no longer stood at the top of a city's social pyramid, their families were by no means usually impoverished nor had they been relegated to the lower classes. The city councils had lost room to maneuver compared to the high imperial period, but they still possessed their own revenues and represented a substantial part of the city's elites. Above all, the declining importance of the councils must by no means be equated with the decline of the ancient cities, which in the Roman Orient and in North Africa still remained very vital in many respects well beyond the 4th century. Only in the west, above all in northern Gaul, is it possible to speak of a decline of urban life already in the 4th century. Conversely, Julian was clearly not the only emperor of the 4 th century who had tried to maintain the efficiency of municipal self-government. All the emperors considered this goal worthwhile and often proclaimed it publicly. For this

45 Seiler, Konstantios II. bei Libanios ( $\rightarrow$ iii.5).

46 Rilinger, "Imperium Romanum als 'Zwangsstaat"; Meier, "Das späte römische Kaiserreich"; Wiemer, "Staatlichkeit und politisches Handeln". 
reason, the privileges Constantine granted to the Christian clergy had already been reduced considerably by his sons. ${ }^{47}$

Until the 1980 os most scholars were convinced that, as a legislator, Julian was pursuing a political course fundamentally different from that of his predecessors. They believed that Julian's measures were closely connected and stemmed from a single creative impulse. For them, Julian was a reformer who put his program into practice, or at least tried to do so. According to this view, the emperor was not only indefatigable: he acted according to a firm and preconceived plan. This interpretation was based on the implicit assumption that Roman emperors acted like modern governments, being committed to implementing programs through laws of general and indefinite validity whenever and as long as they could do so. It is the notable achievement of the British historian Fergus Millar to have shown that this does not fit the conditions of the Roman Empire. As Millar explained in his ground-breaking book "The Emperor in the Roman World" (1976), Roman emperors usually only took action when they were called upon to intervene by reports, inquiries, and requests from functionaries, communities, or individuals. To be sure, the way in which emperors or their representatives decided in similar cases followed rules that were formed by custom. However, it was rare for the imperial centre to take the initiative of its own accord. At its core, the governmental activity of Roman emperors consisted of solving concrete problems that were brought to them 'from below'. In this sense, the Roman monarchy was reactive and casuistic if by no means passive. ${ }^{48}$

Although this new model was initially developed for the early and high imperial period, it also has later proved its heuristic value for the late Roman Empire, albeit with certain modifications. The regulatory density increased under Diocletian and his successors as the state apparatus grew, especially as its very

The fundamental study of the Late Roman city is Liebeschuetz, Roman City. The collected volumes edited by John Rich (The City in Late Antiquity) and by Jens-Uwe Krause and Christian Witschel ("Die Stadt in der Spätantike") contain important regional studies. The cities of Late Roman North Africa have been studied exhaustively by Lepelley, Les cités de l'Afrique romaine. Witschel, "Sterbende Städte?" provides a well-informed, up-todate overview on Late Roman urbanism. Laniado, Les notables municipaux treats the development of the curial class in the Late Roman East. Schmidt-Hofner, "Städtische Finanzautonomie" has demonstrated that there was no general confiscation of civic revenues under Constantine, as many scholars have supposed. On the policies of Constantine's sons see Vogler, Constance II et l'administration impériale; Chastagnol, Le monde romain 284-363; Maraval, Les fils de Constantin.

48 Millar, Emperor, thoroughly reviewed by Bleicken, Zum Regierungsstil des römischen Kaisers. Millar defends his position against critics in the epilogue to the second edition (1992). 
functioning required permanent regulation. The administration of the provinces was intensified by breaking larger provinces up into smaller ones and the collection of taxes was reorganized in a systematic way. But the spheres of governmental activity remained unchanged with one major exception: religious policy. In this area, the alliance between the emperor and the bishops struck by Constantine did indeed lead to an expanded claim for regulation, as Christians of all persuasions expected the emperor to stand up for the true faith. Apart from that, late Roman legislation and administration was primarily characterized by reactive routine. Innovative measures that served the purpose of systematic organization remained rare exceptions. As Sebastian Schmidt-Hofner has shown, this also applies to the legislative activity of Julian's successors, even if in some areas they actually introduced administrative reforms for the entire territory of the empire. ${ }^{49}$

This new model of imperial action was able to prevail in research on the late Roman Empire not least because scholars had learned better to appreciate the peculiarities of late Roman legislation. ${ }^{50}$ As long as the normative acts assembled in the "Codex Theodosianus" were thought to resemble the laws enacted by modern states and drawn up as legal codes, scholars were a priori inclined to attribute to them an unlimited validity across the empire and to regard their content as innovative unless other evidence indicated the contrary. This approach was based on the idea that the primary purpose of late Roman legislation had been to impose new law that was to be applied everywhere and at all times. On this view, the imperial court was the directing centre from which all these regulations emanated. The large number of more or less identical decrees on the same subject area was consequently regarded as an expression of a comprehensive claim to regulation, but, at the same time, part of the research viewed the frequent repetition of similar rules as an indication that the state was unable actually to enforce this claim: Although the late Roman state wanted to regulate many things, in reality it was unable to ensure that its decrees were being obeyed. In fact, however, very few of the 'laws' included in the "Codex Theodosianus" are to be understood as normative acts that created new law, and only a small number claim validity throughout the empire. The vast majority merely confirm or explain existing regulations on a given occasion. As a rule, the scope of application corresponded to the jurisdiction of the functionary, who is named as the addressee. All the laws of late Roman emperors were stylized as letters that had specific audiences. These addressees were

49 Schmidt-Hofner, Reagieren und Gestalten; Schmidt-Hofner, "Ostentatious Legislation".

50 Schmidt-Hofner, Reagieren und Gestalten, pp. 111-36 sets out the issues with exemplary precision and clarity. 
almost always civil functionaries of the emperor, from the praetorian prefects downwards. Only few legal pronouncements were addressed to the Senates of Rome and Constantinople (these were then called orationes, 'speeches'). Often the addressee had previously asked the imperial centre to explain a rule or to confirm its validity; in such cases the legislation reacted by affirming and explicating the law in force, occasionally also by modifying it. Conversely, even in Late Antiquity policies aiming to shape society according to a deliberate plan were more the exception than the rule - even though regulatory density had increased tremendously compared to the early imperial period.

The re-evaluation of late Roman legislation had far-reaching consequences for the understanding of Julian's government. Earlier scholars often assumed that Julian had implemented new law through his legislation, which is why he was considered a reformer. This assessment reproduces Julian's self-representation, since he polemicized against his predecessors and proclaimed the restoration of the empire and the cities as his political aim. The innovative character of Julian's legislation was taken for granted and only called into question when earlier regulations of similar substance were handed down. It used to be overlooked that the 'laws' of the Constantinian dynasty presuppose a whole system of norms that must be reconstructed because these were never systematically explicated. Bearing this in mind, it soon becomes clear that in many cases Julian's 'laws' were not innovative but affirmative: They merely perpetuated what was already law before him. It is therefore important not to interpret Julian's legislative measures in isolation, but in the context of a system of norms that already existed. The motivation of his legislative activities is only revealed when one considers how they came about. With Julian, as with every other late Roman emperor, it is thus always necessary to inquire about the situational context in which a legislative measure was taken: Did the emperor act on his own initiative or did he respond to an inquiry or request he was confronted with? Did he establish new law or did he simply affirm a regulation that had already been in force but was unknown or unclear to the subjects?

The Italian legal historian Manlio Sargenti (1915-2012) pointed out as early as 1979 the need to consider Julian's legislative measures in the light of these considerations. ${ }^{51}$ The German historian Edgar Pack was the first to implement this methodology consistently. In his book "Cities and Taxes in the Policies of the Emperor Julian" (Städte und Steuern in der Politik Julians, 1986), he interpreted the government of Julian as a mixture of clever propaganda and short-sighted improvisation: In many cases the emperor had reacted with his legislation to problems that he had himself created by usurping the rank of Augustus. The 
programmatic promises, Pack observes, were greatly exaggerated, the measures taken to implement them contradictory and ineffective. Pack exposed the reformer Julian as an ideological mirage:

What has traditionally been claimed to be the consistent and coherent policy of a reformer, turns out on closer inspection to be a self-revision of the 'reformist' approaches that was completely independent of the will and planning of the 'reformer' ('reform as autokinesis') and occasionally even as outright emergency legislation, whose necessity the emperor himself had triggered or reinforced with his ambitious and possibly overly hasty Persian war plan. ${ }^{52}$

One does not have to agree with this exceedingly negative general assessment of Julian's legislation. The blatant contradiction between his self-representation as patron and the priority of fiscal interests is no more specific to Julian than the reactive and situational character of much of his legislation. In this respect, Pack's verdict is less a condemnation of Julian than of the late Roman state in general. Nevertheless, Pack's monograph has unquestionably raised the bar for research on Julian's legislation. There should be no retreat from the insights he has provided. ${ }^{53}$

Since Julian came to power as a usurper, he lacked legitimacy in the eyes of the former subjects of Constantius. He had revolted against his cousin Constantius, who was considered the legitimate Augustus almost everywhere outside Gaul. Julian therefore had to go to great lengths to win over the relevant groups in the army, the central authorities, and the Senates of Rome and Constantinople. For every one of Julian's actions and public pronouncements from the time of his usurpation onwards, we must therefore ask whether it served to justify his claim to sole rule. Especially in the case of an emperor who communicated so frequently and in such diverse forms with his subjects, the normative acts also had a communicative function that has often been underestimated: 'laws' were one medium among several others by which emperors

$52 \quad$ Pack, Städte und Steuern ( $\rightarrow$ i.8), p. 383: "Was in dieser Hinsicht traditionell als reformerische Konsequenz und Kohärenz in Anspruch genommen wurde, entpuppte sich bei genauerem Zusehen als von dem Willen und der vorausschauenden Planung des 'Reformers' ganz unabhängige, unfreiwillige Selbstrevision der 'reformerischen' Ansätze ('Reform als Autokinese') und mitunter sogar als eine ausgesprochene Notstandsgesetzgebung, deren Notwendigkeit der Kaiser mit seinem ehrgeizigen und vielleicht überstürzten Perserkriegsplan selbst herbeigeführt oder verstärkt hatte".

53 Renucci,Les idées politiques $(\rightarrow \mathrm{i} .2)$ falls far behind Pack. Brendel,Julians Gesetzgebungswerk $(\rightarrow \mathrm{i} .8)$ does not advance beyond him. 
could curry favor with their subjects, particularly when such 'laws' were being posted in public, as was often the case with Julian. It goes without saying that Julian's reign as Caesar in Gaul is also to be regarded from this point of view, although at that time he was not allowed to issue legal pronouncements in the form of constitutions. This is particularly true if one assumes that Julian was not as completely surprised by his elevation to Augustus as he claimed. If, on the contrary, he had planned or at least favored it, his actions as Caesar can and should also be interpreted as preparation for a confrontation with Constantius (as earlier research had already done to some extent). ${ }^{54}$

Finally, the reappraisal of Julian also includes a deeper understanding of his philosophical positions. Recent research has dismissed the notion of an enlightened and tolerant philosopher-emperor. The modern reconstructions of social philosophy and theories of domination inspired by Neoplatonism open up new perspectives on the monarchic self-representation of the emperor and its roots in the history of ideas. Largely by recourse to Plato's "Laws", Julian developed the idea of a monarch who, on the basis of his own reason, voluntarily submits to the law and whose claim to legitimacy is derived from this compliance. He rejected the idea that the emperor was a "living law" (nomos empsychos) and as such exempt from the laws of the state, and he also took pains in his public appearances to avoid the impression that he was acting autocratically. Julian presented himself as a monarch who safeguards the traditional order and respects the equality of all before the law. ${ }^{55}$

This "Companion to Julian" aligns itself with the research traditions summarized above. In terms of his personality, Julian therefore remains in the background as an ultimately elusive figure. There is no chapter about his youth, his character, or his "apostasy". We do not mean to reject the validity of a biographical approach, however. Julian's writings invite us to regard him as a human being, because the author speaks of himself at length and in many places. Notwithstanding many gaps, it is possible to tell the story of Julian's life, from his birth to his death. As long as we appreciate the limits of what can be discovered biographically, there is no reason to object to this approach. And, of course, the question of how we should understand Julian's commitment to the ancient gods remains intriguing and legitimate. ${ }^{56}$

54 The case for a planned usurpation was forcefully put by Müller-Seidel, "Usurpation Julians" ( $\rightarrow$ i.7) - an article derived from a dissertation submitted at the university of Heidelberg in 1945. See now Bruno Bleckmann at Ch. IV.

For a comprehensive study of Julian's philosophical ideas see de Vita, Giuliano imperatore filosofo ( $\rightarrow$ i.4); for an up-to-date summary see Riedweg, "Kaiser Julian" ( $\rightarrow$ i.4). Julian's social philosophy is analyzed by Schramm, Freundschaft im Neuplatonismus ( $\rightarrow$ i.4), pp. 306-443.

56 Here, most recently Tanaseanu-Döbler, Konversion zur Philosophie ( $\rightarrow$ i.4), pp. 57-154. 
The editors of this volume have nevertheless deliberately chosen a different approach: The authors deal with Julian as writer and emperor, as legislator, religious reformer, Neoplatonic philosopher and commander, and with the reactions his deeds provoked among contemporaries and posterity. They do not proceed from assumptions about Julian's personality but from his actions and they try to explain them from their respective contexts. The Companion is dedicated to the words and deeds of a late Roman emperor: Julian was born a scion of the Constantinian dynasty, made Caesar by Constantine's son Constantius, and proclaimed Augustus against the latter's wishes; he could only avoid bloodshed and assert his standing as ruler because of Constantius's death. The authors of this "Companion" interpret Julian's words and deeds in the context of the scope for action available to Roman emperors and the expectations their subjects had of them. They classify Julian's rule with other emperors of the 4th century and, in doing so, dispel the spectre of incomparability. Nonetheless, our aim is by no means to portray Julian simply as an 'ordinary emperor' whose government differed at best in certain outward details from those of Constantine and his sons. His project of a 'reformation' of ancient polytheism cannot be the product of a calculated striving for power. In our view, Julian's actions as emperor can only be adequately understood by assessing his latitude of action and by comparing the way he used it with the actions of other emperors of his time. This also means that Julian's writings are usually not interpreted for their own sake, whether from a literary or a philosophical perspective. The interpretation of the texts rather serves the ends of furthering historical knowledge. This "Companion" is thus very much a historians' guide to Julian.

\section{Editions, Translations, Resources}

A variety of resources are available today for gaining an understanding of Julian. Almost all texts relevant to this topic are available in critical editions and easily accessed through translations and commentaries; a detailed overview by author can be found in the general bibliography at the end of this book. The essential edition of Julian's Letters (1922) is the work of Joseph Bidez and Franz Cumont; in addition to Julian's genuine letters, it contains letters falsely attributed to him, laws enacted in his name, and fragments of lost writings. The edition of the letters in the Collection Budé (1924), which Bidez alone provided, contains only the genuine letters of Julian, but offers a French translation and explanatory notes. The more recent translations into Italian and German are also based on the Bidez edition; the editions by Bertold Weis (1973) and 
Matilde Caltabiano (1991) are accompanied by extensive notes. The three-volume Loeb edition by Wilmer Wright (1923) which is widely used in the Englishspeaking world offers the text of the Julian edition by Friedrich Hertlein (1876), which is in many respects obsolete, with nine newly discovered additional letters; it also uses a different numbering.

The publication of Julian's Budé edition dragged on for four decades. After the letters, Bidez also published the writings of Julian, which most certainly date back to the time when he was Caesar in Gaul, including the "Letter to the Athenians". The task of editing the writings, which certainly or at least probably date from the time of Julian's sole rule, was entrusted to Gabriel Rochefort and Christian Lacombrade, whose volumes appeared in 1963 and 1964 respectively. In contrast to the editions of Bidez, which found general recognition, the subsequent volumes met with strong criticism. For this reason, the Italian philologist Carlo Prato set about re-editing the writings of Emperor Julian in the 1980s. He and his disciples have now published almost all of the writings in separate editions with Italian translations and partly also with extensive commentaries. In this context, the extensive commentary on and translation of Julian's first eulogy of Constantius by the Italian historian Ignazio Tantillo also deserves mention. A new critical edition of all Julian's writings from the time of his sole rule (including the "Letter to Themistius") was recently published by Heinz-Günther Nesselrath (2016); his edition contains no translation and does not include the numbering of writings introduced in the Budé edition. All editions (and most translations) of Julian's letters and writings, however, refer to the page count of the 1694 edition of Ezechiel Spanheim.

Spanheim not only presented a complete annotated edition of Julian's letters and writings, he also appended to them an edition of the ten books of Cyril of Alexandria "Against Julian". The German historian Karl Julius Neumann was the first to attempt to reconstruct Julian's lost writing against the Christians from Cyril's retort. His edition was published in 1880 and was accompanied by a German translation, which appeared separately. Wright then translated this text into English for the Loeb edition. Because Neumann mistakenly assumed that Cyril had commented on Julian's text more or less in full, he believed that Julian's first book could be almost completely restored. He therefore had the fragments printed as a continuous text. The same illusion is conveyed by the Loeb edition. Only the new edition of the fragments by Emanuela Masaracchia (1990) gives an accurate impression of the state of preservation of Julian's lost treatise, but it still relies on the same manuscripts of Cyril's treatise that Neumann had used for his edition a century earlier. The first critical edition of Cyril's treatise has only recently been published by Christoph Riedweg, Wolfram Kinzig and others with a German translation and a detailed 
commentary. The Greek text has also been used for the second volume of the edition in the series "Sources chrétiennes" (2016) which as yet only runs to book 5 . What remains to be done is to produce an edition of the fragments of Julian's treatise which takes into account the insights that have been reached by close study of Cyril's text.

Significant progress has also been made in recent decades in the area of historiographical sources. This applies in particular to the historical works of Ammianus Marcellinus and Zosimus. The six-volume Budé edition of AMMIANUS MARCELLINUS was started in 1968 and completed in 2002. In addition to the Latin text and a French translation, all the volumes also contain detailed commentaries. The notes of the French philologist Jacques Fontaine on the books 20-22 and 23-25 are particularly important for research on Julian. The Swiss historian Joachim Szidat has dedicated a detailed commentary to the books 20-21. The commentary on Ammianus Marcellinus which the Dutch scholar Pieter de Jonge began in 1935 and has been continued since the 1980s by a group of Dutch scholars, has recently been completed. The annotated bilingual edition produced by the East German historian Wolfgang Seyfarth (1968-1971), who later published a critical edition of the Latin text in the Teubner series (1978), is also useful. An annotated translation into German by Otto Veh and Gerhard Wirth came out in 1974. A new complete translation into English represents an urgent desideratum, since the Loeb edition by John Rolfe which faute de mieux is still widely used, dates from a time when none of the aforementioned commentaries were available.

With the six-volume Budé edition, the Swiss historian François Paschoud has created, in a decade-spanning effort, an indispensable working tool for the historical work of Zosimus. In addition to the Greek text and French translation, this edition contains extensive notes that mainly deal with factual problems and source questions. Beyond this, there are now modern translations of Zosimus into English by Ronald Ridley (1982) and into German by Otto Veh and Stefan Rebenich (1990). What survives of the historical work of EunAPIUS can be found most conveniently in Roger Blockley's collection "The Fragmentary Classicising Historians of the Later Roman Empire" (1983), which also offers an English translation. For a long time, the "Lives of the Sophists" of Eunapius were only available in an edition from the early 19th century, on which the Loeb edition of Wilmer Wright (1921) is based. The first critical edition was published in 1956 by the Italian philologist Giuseppe Giangrande. Since the turn of the millennium, the text has been translated several times and extensively annotated: In 2007 by Maurizio Civiletti (Italian), in 2013 by Matthias Becker (German) and in 2014 by Richard Goulet in the Budé series (French). Goulet has also reconstituted the Greek text. 
Over the last decades, the Christian historiographers of the $5^{\text {th }}$ century, SOCRATES, SOzomen, AND Theodoret have also become much more accessible. While critical editions of Sozomen (by Joseph Bidez) and Theodoret (by Léon Parmentier) in the series "Griechische christliche Schriftsteller" (Greek Christian Writers) already appeared before the First World War, the edition of Socrates prepared by Christian Günther Hansen could not be published until after the end of the GDR in 1995. Today, all three historical works are also available in the series "Sources chrétiennes" with French translations and commentaries: The four-volume edition of Socrates was published between 2004 and 2007, the four-volume edition of Sozomen between 1983 and 2008, and the two-volume edition of Theodoret's "Church History" between 2006 and 2009. Since 2004, Sozomen has also received a bilingual edition by Christian Günther Hansen in the series "Fontes Christiani", which contains explanatory notes in addition to a German translation. In the English-speaking world, one still relies on the translations in the series "The Writings of the Nicene and PostNicene Fathers", which appeared in Oxford between 1890 and 1900. The situation is better for the fragments of the "Church history" of PhiLostorgius, which Joseph Bidez published already in 1911. The English translation published by Philip Amidon in 2007 is also based on this edition. Since then, the monumental edition by Markus Stein and Bruno Bleckmann (2015), which includes a German translation and a thorough and far-ranging commentary, has greatly enhanced the understanding of this text. An abridged version of this commentary is also included in the bilingual edition of the series "Sources chrétiennes" (2013).

There is also no shortage of critical editions and modern translations of the authors of small-format historical works in Latin. The so-called Breviaria of Aurelius Victor, Eutropius, AND Festus are all available with French translations and commentaries in the Budé series. Aurelius Victor and Eutropius have also been translated into English, German, and Italian. In 1967, John Eadie dedicated an edition with English commentary to Festus, which was followed in 2009 by an edition from Maria Luisa Fele with Italian translation and commentary. In 2018, the "Breviarium" of EutropIUs was edited by Bruno Bleckmann and Jonathan Groß with German translation and commentary.

The sources of rhetorical character have also been made accessible through a variety of tools. Until the 196os, the speeches and letters of Libanius were only accessible in the Teubner edition of the German philologist Richard Förster, which appeared between 1903 and 1927 and is still fundamental. For research on Julian, the Loeb edition of the "Julianic Orations" of the British philologist A.F. Norman published in 1969 was therefore a notable event. It also contains the "Funeral speech over Julian" (Oration 18) and the speech "Revenge 
for Julian" (Oration 24) with a generally reliable English translation and explanatory notes. The latter speeches were translated into German by Werner Portmann and others in 2002. The letters of Libanius from the time of Constantius and Julian have been translated into English by the American historian Scott Bradbury, who has made them accessible to a wider readership for the first time (2004). A critical edition of the speeches of HIMERIUS was published by Aristides Colonna in 1951. Translations into modern languages appeared only after the turn of the millennium: Harald Völker's unreliable translation into German came out in 2003. A translation into English by Robert Penella, with introduction and commentary, was issued in 2007. The panegyric of Julian by Claudius MAMERTINUS was studied half a century earlier by the Swiss philologist Hans Gutzwiller who in 1942 edited the Latin text with a German translation and commentary. Samuel Lieu and Marna Morgan published an English translation in 1986.

The same source book on Julian edited by Samuel Lieu which contains the English translation of the "New Year's Speech" of Claudius Mamertinus also includes an annotated English translation of the "Hymns against Julian" composed by the Syrian theologian and poet EpHrEM; while the translation was made by Judith Lieu, the notes have been added by Samuel Lieu. The Syrian text had already been published in 1957 by Edmund Beck (with a German translation). Finally, our understanding of the invectives of GREGORY OF NAZIANZUS has also grown considerably in recent decades. In 1983 Jean Bernardi brought out the first critical edition of these two speeches (Oration $4+5$ ) in the series "Sources chrétiennes", which was accompanied by a French translation. In 1988, Alois Kurmann published a detailed commentary on the first of the two invectives. Finally, Leonardo Lugaresi published an annotated edition with Italian translation in 1993 and 1997 respectively. The situation is less than satisfactory in the English-speaking world, where one still has to rely on the translation by Charles William from 1888.

By way of conclusion, the legal, epigraphic, numismatic, and pictorial sources for Julian deserve brief mention. Access to Julian's legislation has since 1919 been provided by Otto Seeck's fundamental study "Die Regesten der Kaiser und Päpste" (Regesta of the Emperors and Popes), which compiled all datable acts of late Roman emperors in the form of chronological charts. Because the dates of the 'laws' preserved in the "Codex Theodosianus" are in many cases demonstrably corrupted, Seeck often felt required to emend the transmitted dates. Subsequent research has often, but by no means always, accepted his suggestions. In 2009, Emilio Germino collected more recent proposals on the dating and authorship of laws that are rightly or wrongly associated with Julian. In 2017 Raphael Brendel summarized and discussed the research on these 
texts; his work is useful as a catalogue of the laws and as a bibliographical survey. ${ }^{57}$ A previously unknown constitution of Julian dealing with advocates practising at the bar of the urban prefect of Rome was published in 1963 by Bernhard Bischoff and Dieter Nörr with a German translation and a detailed commentary. This rescript was not included in the "Codex Theodosianus"; it only survives in a manuscript with the comedies of the Roman playwright Terence which was written in the 1oth or 11th century. ${ }^{58}$ It is very rare for laws preserved in the "Codex" to be known from inscriptions or papyri. A fragmentary papyrus found in the Fayum (Egypt) preserves parts of an edict in which an emperor proclaims that for his succession as Augustus he will not levy the "crown gold" (aurum coronarium) that was due at the beginning of a reign. As the "Codex Theodosianus" (12.13.1) preserves a law of Julian declaring payment of the "crown gold" to be a voluntary act he was often considered to be the author of the papyrus edict in earlier research, but the papyrus edict is now almost unanimously attributed to Alexander Severus and thus dated roughly a century earlier. ${ }^{59}$ An abridged version of Julian's law on the appointment of assistant judges (iudices pedanei) in the "Codex Theodosianus" (1.16.8) has been passed down almost in full through an inscription found in Minoa on the island of Amorgus. Denis Feissel devoted an exhaustive study to this unique case in 2000.60

Javier Arce was the first to produce a collection of Latin and Greek inscriptions related to Julian; his repertory came out 1984 . Stefano Conti studied these texts again and in 2004 published a corpus which was based on autopsy of the surviving stones. This corpus has made it very easy to gain an overview of the inscriptions that bear on Julian's reign. Inscriptions published after the corpus was completed, mostly milestones, can be found in the epigraphical journals "L'année épigraphique" and "Supplementum epigraphicum Graecum". In 1981, after decades of work on Julian's coins, John Kent brought out a comprehensive catalogue in the eighth volume of the "Roman Imperial Coinage" which has not yet been superseded. Since then many articles on specific topics have

57 Seeck, Regesten; Germino, "Legislazione dell'imperatore Giuliano" ( $\rightarrow$ i.8); Brendel, Julians Gesetzgebungswerk $(\rightarrow \mathrm{i} .8)$.

$5^{8}$ Bischoff/Nörr, Konstitution Kaiser Julians.

59 The papyrus (P.Fayum 20) was first published in 1900 and is included as no. $72 \mathrm{~b}$ in the invaluable collection of Julian's letters and laws published by Joseph Bidez and Franz Cumont in 1922. The standard edition is Oliver, Greek Constitutions, pp. 529-41 no. 275 (with an English translation). For discussion and exhaustive bibliography see now Brendel, Julians Gesetzgebungswerk ( $\rightarrow$ i.8), p. 301-6.

6o Feissel, "Constitution de l'empereur Julien" ( $\rightarrow$ i.3). The inscription found on Amorgus was first published by Theodor Mommsen in 1873 as CIL III 2, 499a. A very fragmentary inscription found in Mytilene once contained the same text (CIL Suppl. 2, 14198). 
been added, particularly on the bronze coins showing a standing bull crowned by two stars, with interpretations ranging from a zodiacal sign to a symbol of Mithraism or solar religion, even good state governance. ${ }^{61}$ The portraits of Julian were studied by Raissa Calza within the context of the imperial iconography of the late 3 rd and early 4 th centuries (1972) and by Hans-Peter L'Orange in connection with the portraits of the Tetrarchs and the Constantinian Dynasty (1984). Since then, Thomas Fleck has examined all alleged or actual portraits of Julian in a dissertation which was published in 2008. Two famous, almost identical marble statues of a bearded man wearing a tunic, a Greek mantle, and multi-tiered crown have long been considered to be portraits of Julian. Both of them are on display in Paris (one acquired for the Louvre in 1803, the other for the Musée de Cluny in 1859). Today, however, the statue in the Musée de Cluny is dated to the 2nd century and thought to represent a priest of Sarapis while the statue in the Louvre probably is a modern copy. ${ }^{62}$

\section{Modern Literature Not Listed in the General Bibliography (which includes all titles marked with an arrow)}

Auer, J. E., Kaiser Julian der Abtrünnige im Kampfe mit den Kirchenvätern seiner Zeit, Wien 1855

Bleicken, J., Zum Regierungsstil des römischen Kaisers. Eine Antwort auf Fergus Millar (Sitzungsberichte der wissenschaftlichen Gesellschaft der Johann-WolfgangGoethe- Universität Frankfurt am Main, 18, 5), Wiesbaden 1982

Bodin, J., Methodus ad facilem historiarum cognitionem, Paris 1566; English transl. New York 1945

Bouffartigue, J., "Julien entre biographie et analyse historique", Antiquité Tardive 17 (2009), 79-9o

Brown, P., "The Last Pagan Emperor: Robert Browning's The Emperor Julian", Times Literary Supplement 8 April 1977, pp. 425-26; repr. in id., Society and the Holy in Late Antiquity, Berkeley etc. 1982, pp. 83-102

61 Kent, Roman Imperial Coinage viII. Brendel, "Münzprägung Kaiser Julians” ( $\rightarrow \mathrm{i} .2)$ surveys the numismatical literature on Julian published after RIC virI. See also the general bibliography.

62 Calza, Iconografia Romana imperiale ( $\rightarrow$ iv.1), pp. 75-81 (fonti e testimonianze) + pp. 36491 (iconografia); L'Orange, Das spätantike Herrscherbild ( $\rightarrow$ iv.1), pp. 159-64; Fleck, Die Portraits Julianus Apostatas ( $\rightarrow$ iv.1). The recent attempt of Varner, "Julian's artistic program" ( $\rightarrow$ iv.1), pp. 187-98 to defend the traditional ascription of the palliati in Paris to Julian does not convince. 
Chastagnol, A., L'évolution politique, sociale et économique du monde romain 284-363, Paris 1982, 2nd ed. Paris 1985

Demandt, A., Die Spätantike. Römische Geschichte von Diocletian bis Justinian (284-565 n. Chr.), München 1989, 2nd ed. München 2007

Deschner, K., Kriminalgeschichte des Christentums, vol. 1: Die Frühzeit. Von den Ursprüngen im Alten Testament bis zum Tod des hl. Augustinus (430), Reinbek 1986, Pb. Reinbek 1996

Gibbon, E., The History of the Decline and Fall of the Roman Empire, 6 vols. London 17761788; new edition by D. Womersley, 3 vols., London 1994

Harnack, A., "Julian ('Apostata'), der Kaiser”, Realencyclopädie für protestantische Theologie und Kirche, 3rd ed., vol. Ix (1901), col. 6o9-619

Jerphagnon, L., Julien dit l'Apostat. Histoire naturelle d'une famille sous le Bas-Empire, Paris 1986; 2nd ed. Paris 2008

Jochmann, W. (ed.), Adolf Hitler. Monologe im Führerhauptquartier 1941-1944. Aufgezeichnet von H. Heim, Hamburg 1980

Jones, A. H. M., The Later Roman Empire 284-602. A social, economic and administrative survey, 3 vols., Oxford 1964

Krause, J.-U./Witschel, C., Die Stadt in der Spätantike - Niedergang oder Wandel? (Historia. Einzelschriften, 19o), Stuttgart 2006

Kühlmann, W., “'Romantik der Spätantike?' Julian Apostata bei David Friedrich Strauß und Joseph von Eichendorff", in H.-G. Schwarz et al. (eds.), Fenster zur Welt. Deutsch als Fremdsprachenphilologie, München 2004, pp. 134-43

Laniado, A., Recherches sur les notables municipaux dans l'Empire protobyzantin [Travaux et mémoires du Centre de Recherche d'histoire et civilisation de Byzance. Monographies, 13), Paris 2008

Lepelley, C., Les cités de l'Afrique romaine au Bas-Empire, 2 vols., Paris 1979/81

Liebeschuetz, J.H.W.G, The Decline and Fall of the Roman City, Oxford 2001

Maraval, P., Les fils de Constantin. Constantin II (337-340), Constance II (337-361), Constant (337-350), Paris 2013

Marcone, A., "Giuliano l'Apostata e Alfred de Vigny”, Rivista Storica Italiana 94 (1982), 230-246

Marcone, A., "Il Contro i Galilei di Giuliano edito da Voltaire. Storia - e paradossi - di un pamphlet di polemica religiosa", in A. Bencivenni et al. (eds.), PнILовівLOS. Scritti in onore di Giovanni Geraci, Milan 2019, pp. 545-66

Matthews, J.F., Laying down the Law. A Study of the Theodosian Code, New HavenLondon 2000

Meier, M., "Das späte römische Kaiserreich ein 'Zwangsstaat'? Anmerkungen zu einer Forschungskontroverse", Electrum 9 (2003), 193-213

Millar, F., The Emperor in the Roman World (31 BC-AD 337), London 1977, 2nd. ed. London 1992 
Neveu, B., "Un académicien du Xviıre siècle, traducteur et biographe de l'empereur Julien: L'abbé de la Bletterie", Académie des Inscriptions et Belles-Lettres. Comptes rendus 2000, 93-111

Oliver, J.H., Greek Constitutions of Early Roman Emperors from Inscriptions and Papyri (Memoirs of the American Philosophical Society, 178), Philadelphia 1989

Paschoud, F., “Trois livres récents sur l'empereur Julien", Revue des Études Latines 58 (1980), 107-123

Rich, J. (ed.), The City in Late Antiquity (Leicester-Nottingham Studies in Ancient Society, 3), London - New York 1992

Riikonen, H., Die Antike im historischen Roman des 19. Jahrhunderts, Helsinki 1978

Rilinger, R., "Die Interpretation des späten Imperium Romanum als Zwangsstaat", Geschichte in Wissenschaft und Unterricht 36 (1985), 321-340

Schmidt-Hofner, S., "Die städtische Finanzautonomie im spätrömischen Reich", in H.U. Wiemer (ed.), Staatlichkeit und politisches Handeln im Römischen Reich (Millennium-Studien, 6), Berlin - New York 20o6, pp. 209-248

Schmidt-Hofner, S., Reagieren und Gestalten. Der Regierungsstil des spätrömischen Kaisers am Beispiel der Gesetzgebung Valentinians I. (Vestigia. Beiträge zur Alten Geschichte, 58), München 2008

Schmidt-Hofner, S., "Ostentatious Legislation: Law and Dynastic Change, AD 364-365", in J. Wienand (ed.), Contested Monarchy. Integrating the Roman Empire in the 4th Century AD, Oxford - New York 2015, pp. 67-99

Severyns, A, "Notice sur Joseph Bidez", Annuaire de l'Académie Royal de Belgique 122 (1956), 81-214

Stein, E., Geschichte des spätrömischen Reiches von 284 bis 476 n. Chr., vol. 1: Vom römischen zum byzantinischen Staate, Wien 1928; French transl. Brugges 1959

Vogler, C., Constance II et l'administration impériale, Strasbourg 1979

Wiemer, H.-U., "Staatlichkeit und politisches Handeln in der Römischen Kaiserzeit Einleitende Bemerkungen", in H.-U.Wiemer (ed.), Staatlichkeit und politisches Handeln im Römischen Reich (Millennium-Studien, 6), Berlin - New York 20o6, pp. 1-39

Witschel, C., "Sterbende Städte? Betrachtungen zum römischen Städtewesen in der Spätantike", in A. Lampen/A. Ozawar (eds.), Schrumpfende Städte. Ein Phänomen zwischen Antike und Moderne, Köln etc. 2008, pp. 17-78 